\title{
Izboljšanje javne participacije pri prostorskem načrtovanju s pomočjo orodij spleta 2.0
}

Javna participacija (ang. public participation) je ena od oblik sodelovanja oziroma udeleževanja javnosti v postopkih prostorskega načrtovanja, ki omogoča posameznikom in skupinam, da izrazijo svoja mnenja, dajejo pobude in aktivno sodelujejo $\mathrm{v}$ teh postopkih. Ker je javna participacija pogosto omejena le na dajanje pripomb na že pripravljene prostorske načrte, predvidevamo, da bi jo lahko izboljšali s pomočjo informacijskih tehnologij, in sicer $\mathrm{z}$ uporabo novih spletnih orodij. Ena takih novosti je splet 2.0 (ang. web 2.0), koncept, ki je bil prvič predstavljen v letu 2004 in je v svetovni splet prinesel veliko orodij, ki jih koristno uporabljajo socialna omrežja in različne spletne storitve kot participatorne storitve $\mathrm{z}$ velikim številom uporabnikov. V članku so analizirane možnosti za medsebojno interakcijo javne participacije in spleta 2.0. Predstavljene so zahteve javne participacije $\mathrm{v}$ postopkih prostorskega načrtovanja, osnovna orodja spleta 2.0 in njegove zmožnosti glede omogočanja participacije $\mathrm{v}$ procesih prostorskega načrtovanja. $\mathrm{V}$ prispevku je ugotovljeno, da so orodja spleta 2.0 zelo uporabna za vključevanje javnosti v procese prostorskega načrtovanja, vendar zahtevajo veliko predpriprav in dobro tehnično osnovo.

Ključne besede: participacija, javna participacija, e-participacija, prostorsko načrtovanje, splet 2.0, socialna omrežja, spletna orodja 


\section{Uvod}

$» V$ proces urbanističnega planiranja skušamo čim bolj vključiti javnost. Ta bo ,potrošnik' našega dela, saj bodo v mestu, ki ga načrtujemo, ljudje živeli.« (Pogačnik, 1999: 113.) Kot ugotavlja Andrej Pogačnik, je za uspešno prostorsko načrtovanje potrebno tudi sodelovanje oziroma udeleževanje javnosti - javna participacija. Dodaja tudi, da je vključevanje javnosti pogosto omejeno le na komentiranje že pripravljenih prostorskih načrtov, kar velikokrat povzroči odpor do ponujenih načrtovalskih rešitev, nekritično zavračanje novosti in vsesplošno negodovanje javnosti. Prostorsko načrtovanje sicer lahko razumemo kot strokovni tehnični proces, vendar ga moramo nujno razumeti tudi kot politično delovanje. Pri prostorskem načrtovanju gre za interese politike, kapitala in različnih interesnih združenj, ki usmerjajo in želijo uveljaviti svoje interese ali interese lokalne skupnosti (Ploštajner, 2003). Če na prostorsko načrtovanje gledamo z vidika političnega odločanja o prihodnosti neke skupnosti, potem moramo participacijo obravnavati kot del demokratičnega procesa. Pri tem lahko prihaja do nesoglasij med javnostjo, prostorskimi načrtovalci in investitorji ter občinami in državo kot naročniki. Nesoglasja največkrat izvirajo iz zavračanja zamisli prostorskih načrtovalcev $s$ strani javnosti in naročnika. Participacija ni mogoča, če na strani pripravljavcev in naročnika prostorskih dokumentov ni pripravljenosti za poslušanje in sprejemanje drugih mnenj, ki niso nujno strokovna. Obenem pa je javnost dovzetnejša za sodelovanje, če je participacija bolj osredotočena na bistvo načrtovanja, to je na zagotavljanje kakovostnejšega bivalnega okolja in zadovoljstvo prebivalcev. Politična konotacija pri prostorskem načrtovanju je lahko dejavnik, ki širšo javnost odvrne od participacije. Seveda se lahko javnost organizira tudi sama, kar pa je v sedanji praksi zelo težko. Naloga prostorskih načrtovalcev je, da razjasnijo probleme, ki nastanejo $\mathrm{v}$ procesu prostorskega načrtovanja, zbližajo različna stališča ter $s$ tem zagotovijo učinkovitost priprave in izvedbe prostorskih načrtov. Interakcija med načrtovalci in javnostmi je zato nujna.

Prvi pravno zavezujoči dokument Evropske unije, ki ureja vprašanje participacije njenih prebivalcev v okoljskih zadevah, je Aarhuška konvencija, ki jo je na četrti ministrski konferenci leta 1998 sprejela regionalna konvencija evropskih držav članic, njihovih gospodarskih združenj ter držav s posvetovalnim statusom pri gospodarski komisiji Združenih narodov za Evropo. Konvencija je osnova za direktivo o dostopu javnosti do informacij o okolju ter direktivo o sodelovanju javnosti pri sestavi nekaterih načrtov in programov v zvezi z okoljem (glej Evropska komisija, 2003a, 2003b). Na podlagi konvencije in obeh direktiv je tudi Slovenija sprejela zakone, ki so usklajeni z njimi. Med zadnjimi veljavnimi sta Zakon o prostorskem načrtovanju (Ur. l. RS, št. 33/2007 in nadaljnje spremembe) in Zakon o umeščanju prostorskih ureditev državnega pomena v prostor (Ur. l. RS, št. 80/2010). Oba zakonsko opredelita vključevanje javnosti v procese načrtovanja. Določeno je, da mora biti javnost obveščena o postopkih priprave in sprejemanja prostorskih načrtov in da ima pravico sodelovati s pobuda$\mathrm{mi}, \mathrm{z}$ mnenji ali na druge načine, ki so v skladu z zakonom. $\mathrm{V}$ Zakonu o prostorskem načrtovanju (Ur. l. RS, št. 33/2007 in nadaljnje spremembe) ni zaznavna vloga ministrstva, ki je organ sankcioniranja in nadzora, prav tako ni nikjer viden njegov interes za aktivno sodelovanje širše javnosti. Pripravljavci prostorskih načrtov sicer obveščajo javnost o poteku stopenj dela in ji tudi dovolijo sodelovati, vendar le med javno razgrnitvijo že pripravljenih prostorskih dokumentov. Različne javnosti zato vse bolj zahtevajo, da so del celotnega procesa načrtovanja, da imajo besedo že $\mathrm{v}$ začetku procesa in tudi med procesom ter na koncu, pri izbiranju končnih rešitev (Ogorelec, 1995).

Predvidevamo, da bi lahko ustvarjalnejše sodelovanje javnosti zagotovili s pomočjo novih orodij, ki (dnevno) nastajajo in se pojavljajo na svetovnem spletu. Če bi bila javnost seznanjena $s$ potekom načrtovanja, bi lahko svoje predloge, zamisli in poznavanje prostora, $\mathrm{v}$ katerem biva in ustvarja, prek spleta redno posredovala že v zgodnejših fazah načrtovanja. To bi načrtovalcem velikokrat omogočilo lažje načrtovanje in manj negativnih odzivor javnosti ob ponujenih rešitvah. Namen članka je:

- predstaviti javno participacijo $\mathrm{v}$ splošnem in javno participacijo v postopkih prostorskega načrtovanja in ugotoviti, katere vrste komuniciranja z javnostjo v sociološkem smislu se lahko pri tem uporabljajo;

- opredeliti možnosti za javno participacijo s pomočjo spletnih orodij ter kritično analizirati njihov pomen in vlogo pri aktivnem sodelovanju širše javnosti v postopkih prostorskega načrtovanja.

$\mathrm{V}$ metodološkem smislu temelji prispevek na analizi pomembneǰ̌e znanstvene in strokovne literature o obravnavani temi. Te literature je največs področja javne participacije in participacije $\mathrm{v}$ prostorskem načrtovanju, zelo malo pa je je s področja javne participacije s pomočjo spletnih orodij in novih oblik spletnih storitev. Članek prinaša v slovenski prostor nova spoznanja, ki so dopolnjena z avtorjevimi analizami (vključena je analiza SWOT), s predlogi in kritičnimi stališči. Obenem odpira tudi dileme za nadaljnja razmišljanja ter izhodišča za prihodnje raziskovalno in aplikativno delo na tem področju.

\section{Javna participacija}

\subsection{Definicija}

Participacija, še posebej participacija v procesih človekovih posegov v prostor, je tema, ki je v znanosti obravnavana že skoraj štiri desetletja. Pionirka na tem področju je Sherry Arnstein (1969: 216), ki meni, da je » [z]amisel participacije javnosti podobna uživanju špinače; nihče nima nič proti njej, saj je 
dobra za zdravje «. Dojemanja ljudi in njihovo razumevanje okolice zelo slikovito opišeta tudi Nicholas Moore in Dave Davis (1997: 5) s starim kitajskim pregovorom $\gg$ Povej mi in pozabil bom, pokaži mi in spomnil se bom, vključi me in razumel bom.«. Pri participaciji so ljudje tisti, ki z udejstvovanjem vplivajo na uspeh. Participacija je uspešna, če so upoštevani zamisli, predlogi in mnenja, ki jih poda javnost. Participacija torej poveča moč posameznika in ljudi, saj jih vključi v procese odločanja in jim omogoči, da $\mathrm{v}$ teh procesih aktivno sodelujejo (Arnstein, 1969).

Participacij je lahko več vrst. Sherry Arnstein (1969) jih je razdelila na osem ravni, te pa na tri podravni, ki si sledijo $\mathrm{v}$ tako imenovani participatorni lestvici (ang. ladder of citizen participation) (slika 1). Kot je razvidno s slike 1, sta na dnu lestvice »manipulacija « (ang. manipulation) in »terapija « (ang. therapy), ki sta namenjeni neparticipiranju javnosti, vendar omogočata izobraževanje in terapijo javnosti. V sredini je »navidezna participacija « (ang. degrees of tokenism), ki se kaže v »informiranju « (ang. informing), »konzultacijah « (ang. consultation) in » spravi (ang. placation). Navidezna participacija se izraža v sprejemanju glasov javnosti, vendar tudi v izvajanju pravice do neupoštevanja javnosti s strani oblasti. Na vrhu lestvice je »participacija « (ang. degrees of citizen power), ki se kaže v »partnerstvu « (ang. partnership), »delegiranju moči« (ang. delegated power) in »javnem nad-

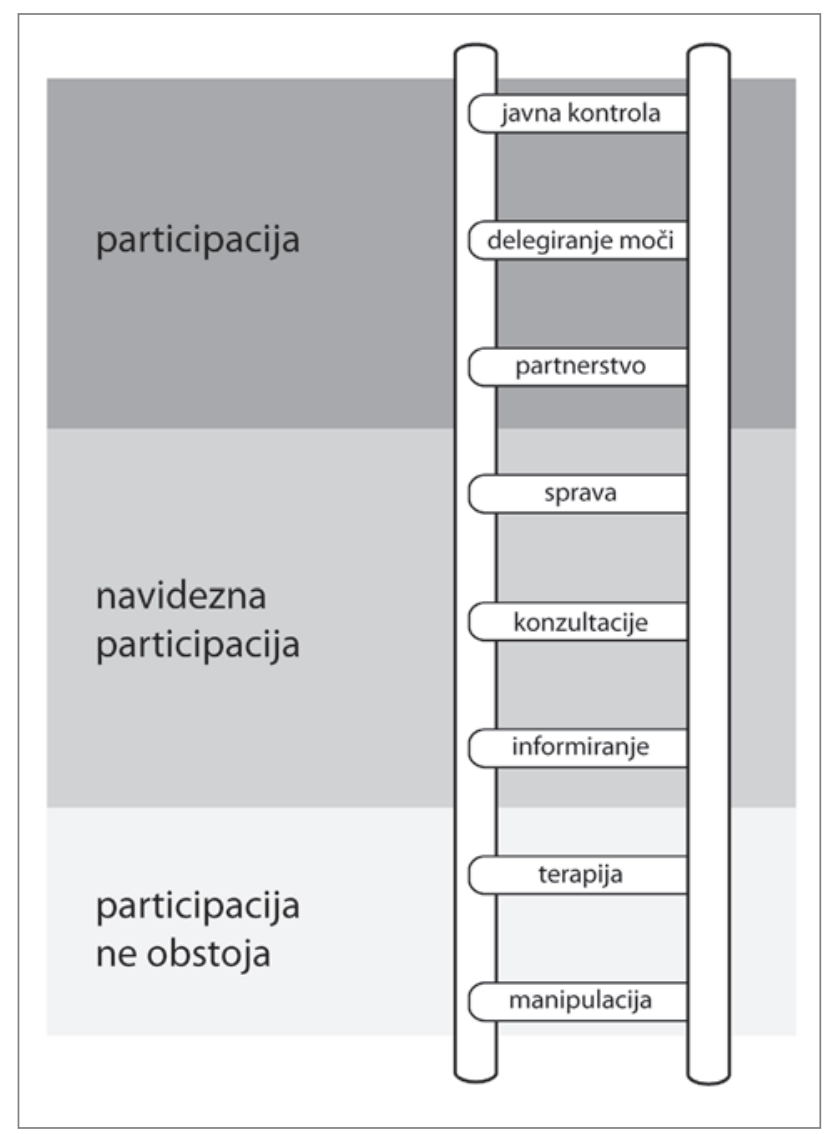

Slika 1: Participatorna lestvica po Sherry Arnstein (1969) zoru « (ang. citizen control). Partnerstvo omogoča izmenjavo mnenj med javnostjo in oblastmi, delegiranje moči in javni nadzor pa omogočata popolno participacijo, saj lahko javnost vpliva na odločitve oblasti. Analize participacij javnosti po tej lestvici so pokazale, da oblastne strukture pogosto ne podpirajo popolne participacije. Namesto tega dajejo več možnosti sodelovanju le določenemu delu javnosti (na primer bogatejšim, mlajšim in podobno) (Carver, idr., 2001). Vendar se s takim ravnanjem odvzame moč posameznikom, od želelnega cilja pa se odvrnejo javnost, civilne iniciative in lokalna združenja (Sieber, 2006). Kot ugotavlja Peter A. Kwaku Kyem (1998), javnost participatornim sistemom, za katere je značilna taka raven participacije (»navidezna participacija «), ne zaupa. Zaradi tega del javnosti sčasoma pri participaciji ne želi več sodelovati.

Nekoliko drugačno lestvico participiranja sta oblikovala Peter M. Waidemann in Susanne Femers (1993). Njuna lestvica sestoji iz šestih stopenj (slika 2). Najnižja je »javnost ima pravico vedeti « (ang. public right to know), sledita ji »informiranje javnosti « (ang. informing the public) in »javnost ima pravico do pritožbe « (ang. public right to object). Stopnji, ki sta že bližje participaciji, sta »javnost participira $\mathrm{z}$ določanjem inte-

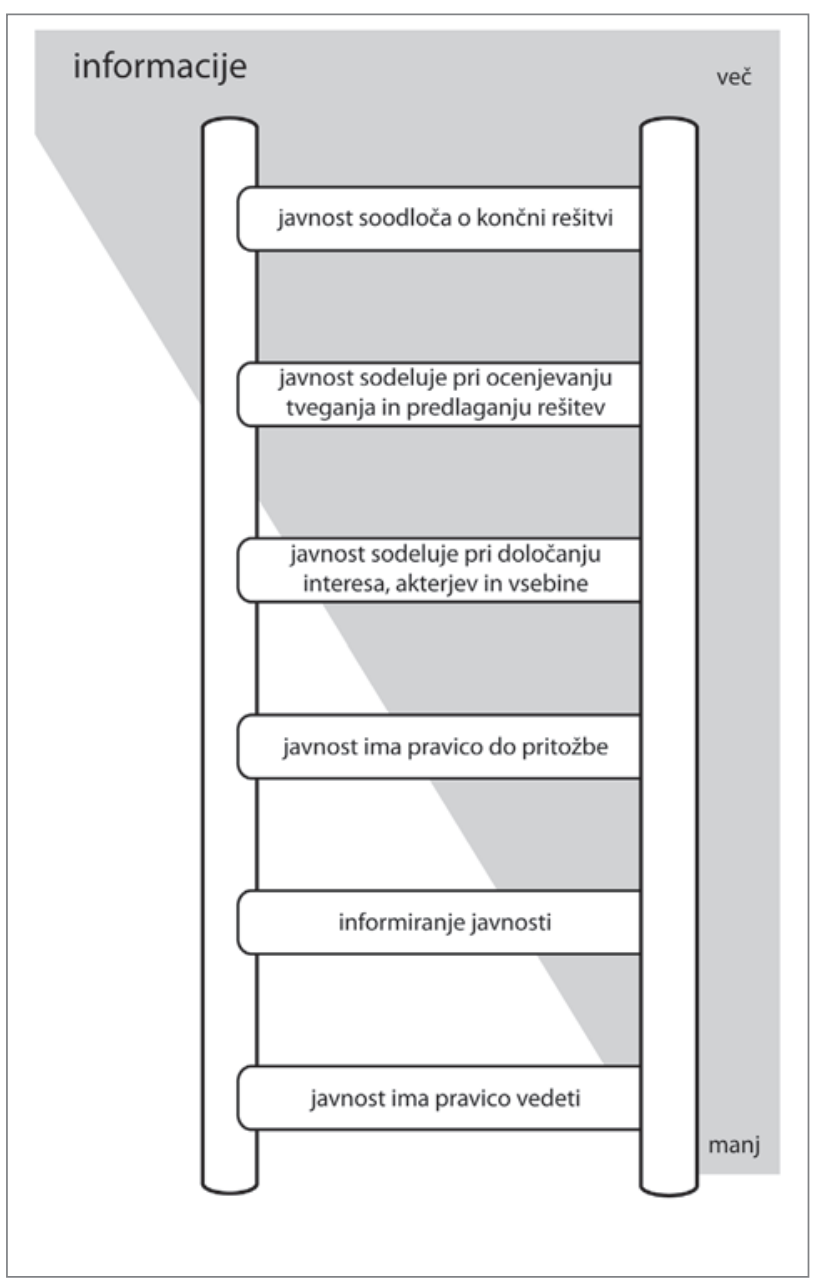

Slika 2: Participatorna lestvica po Petru Waidemannu in Susanne Femers (1993) 


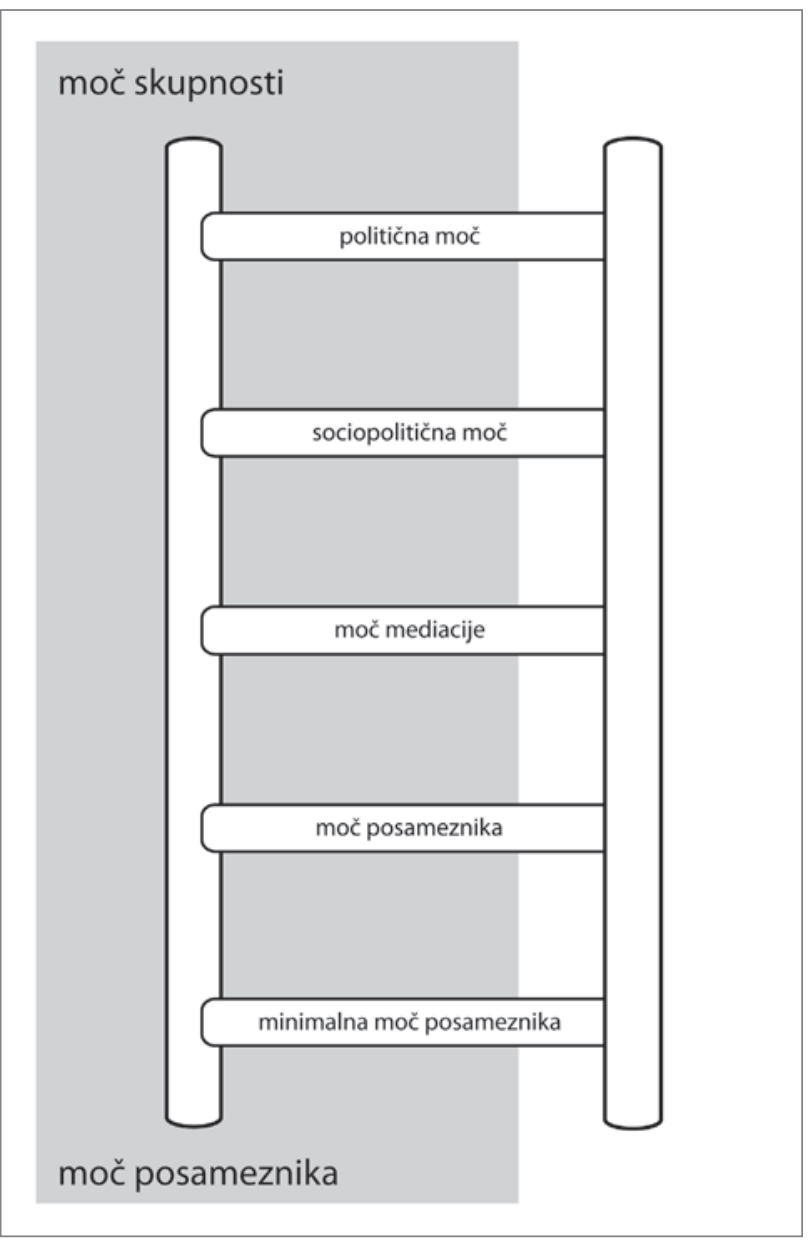

Slika 3: Participatorna lestvica po Elisabeth Roche (1997)

resa, akterjev in vsebine « (ang. public participation in defining interests and determining the agenda) ter $\gg$ javnost participira $\mathrm{z}$ ocenjevanjem tveganja in $s$ predlaganjem rešitev « (ang. public participation in assessing ris kand recommending solutions). $\mathrm{Za}$ dnja stopnja in hkrati stopnja, ki nudi javnosti največjo moč, je »javnost soodloča o končni odločitvi« (ang. public partnership in the final decision). Značilnost te lestvice je, da se stopnja participacije veča s stopnjo dostopa javnosti do informacij. Več ko ima javnost na voljo informacij, večja je njena vloga $\mathrm{v}$ participaciji in moč odločanja, ki jo $s$ tem pridobi.

Lestvica, ki jo je sestavila Elisabeth Roche (1997), ponazarja moč, ki jo lahko ima posameznik pri vplivanju na vedênje drugega posameznika, da bo ta storil nekaj, česar sicer ne bi. Lestvica ima pet stopenj in prehaja od moči posameznika do moči skupnosti. Pri tem se moč posameznika z vsako nadaljnjo stopnjo povečuje in približuje moči skupnosti, kar je v nasprotju s prejšnjimi lestvicami, pri katerih vse poteka v skupnosti. To na dnu lestvice onemogoča, na vrhu pa omogoča, da posameznik kot del skupnosti nekaj doseže.

V vseh predstavljenih participatornih modelih se želi povečati moč posameznika v skupnosti, da se mu omogoči, da vpliva na odločitve, ki zadevajo njegovo življenje. $Z$ vidika prostorskega načrtovanja je najprimernejša lestvica Petra Waidemanna in Susanne Femers (drugi lestvici sta namenjeni bolj politični participaciji, na primer za volitve). Pri tej lestvici so v ospredju informacije in dostop do njih, $\mathrm{v}$ primeru prostorskega načrtovanja informacije o posegih $\mathrm{v}$ prostor. Javnost se lahko na podlagi teh informacij odloči, ali se s predlaganimi posegi strinja ali ne. Če je javnost seznanjena z informacijami v celotnem postopku nastajanja posegov v prostor, se lahko že v okviru postopka odpravijo nekatere nejasnosti, ki se največkrat pokažejo šele pri razgrnitvi prostorskih načrtov. Javna razgrnitev poteka v Sloveniji v časovnici izdelave prostorskih načrtov (občinski prostorski načrt, $\mathrm{v}$ nadaljevanju: OPN; občinski podrobni prostorski načrt, v nadaljevanju: OPPN; državni prostorski načrt, v nadaljevanju: DPN) takrat, ko je že pripravljen dopolnjeni osnutek OPN ali OPPN oziroma osnutek DPN. To je prepozno, saj v tem primeru javnost lahko samo še poda pripombe na prostorski načrt, ki jih izdelovalec upošteva ali zavrne.

\subsection{Oblike javne participacije}

Javno participacijo delimo na:

- Formalno, ki jo določa zakon in je za oblast zavezujoča. Oblike formalne participacije so referendum, ljudska iniciativa, zbor občanov in volitve.

- Neformalno, ki je zakon ne določa in je prepuščena javnosti, ki se odloči o načinu njene uporabe. Med neformalne oblike participacije štejemo posvetovanja, zbiranje podpisov, izvajanje protestov, podpisovanje peticij in zahtev. Neformalne so tudi pobude nevladnih organizacij, pobude za sestanek s predstavniki lokalne oblasti in podobno.

K participaciji pripomore tudi načelo odprtosti, ki opredeljuje transparentnost delovanja javne uprave, zagotavljanje informacij o njenem delu in pravico dostopa do javnih dokumentov. Zahteva pa tudi različne oblike aktivnega sodelovanja in komuniciranja med upravo in državljani. Načelo odprtosti je opredelila Evropska komisija leta 2001 v beli knjigi o evropskem upravljanju (glej Evropska komisija, 2001), v slovenski zakonodaji pa to načelo omogoča Zakon o dostopu do informacij javnega značaja (Ur. l. RS, št. 24/2003). V zakonu je določeno, da morajo organi javne uprave ustrezno urediti svoje spletne strani. Te so poleg ostalih medijev (časopisi, radio, televizija in podobno) po zakonu eden najpomembnejših medijev za dostop do informacij javnega značaja. $Z$ dostopom do informacij javnega značaja je zadoščeno pravilu transparentnosti javne uprave.

Za izpeljavo javne participacije $\mathrm{v}$ prostorskem načrtovanju je uporabno posvetovanje ali konzultacija, ki je kot oblika neformalne participacije delno urejena $\mathrm{v}$ Zakonu o prostorskem načrtovanju (Ur. l. RS, št. 33/2007 in nadaljnje spremembe), in 
sicer že v temeljnih določbah. Pri tem gre za načelo, da imajo prebivalci pravico biti vprašani za mnenje ali povedati mnenje o konkretnem projektu ali predpisu, ki ga predlaga lokalna skupnost ali ministrstvo. V prej omenjenem zakonu je tudi zapisano, da morajo pripravljavci prostorskih načrtov oblikovati stališča o pripombah in predlogih javnosti, ki so podani v okviru javne razgrnitve. Med oblike konzultacij lahko štejemo vprašalnike, delavnice, seminarje, konference, javne predstavitve mnenj, dneve odprtih vrat in podobno. Soodločanje, še ena od oblik neformalne participacije, omogoča prebivalcem tudi udejstvovanje pri pripravi prostorskih dokumentov. Pri konzultacijah prebivalci podajo svoje mnenje in pobude, pri tem pa mora lokalna skupnost nanje odgovoriti. Ni jih sicer dolžna upoštevati, vendar pa pri soodločanju prebivalci skupaj z lokalno skupnostjo že od vsega začetka sodelujejo pri definiciji problema in tudi pri njegovem reševanju (Lavtar, 2007). Javnost ima največ možnosti participacije v procesih prostorskega načrtovanja prav pri neformalni participaciji, saj ni obvezujoča. Prav tako ni nujno politično pogojena, in ker ni natančno določena, si jo lahko javnost priredi za svoje potrebe. Vendar mora pri tem imeti podporo s strani pripravljavcev prostorske dokumentacije in tudi s strani naročnika.

Javna participacija v procesu izdelave prostorskih načrtov in drugih posegov v prostor je del demokratičnega procesa. Vendar je od pripravljavcev dokumentov odvisno, kolikšna bo ta participacija (Carver idr., 2001). Drago Kos (2005) navaja, da participacija v procesu prenove mesta pomeni, da bo prenova legitimna, če omogoča sodelovanje vseh vpletenih, torej pripravljavcev prenove in tudi javnosti, ki ji je prenova namenjena. Izmenjave mnenj med načrtovalci, naročnikom in javnostjo ne more biti brez aktivne participacije slednje. Za doseganje te pa je treba po Zhongu-Renu Pengu (2001) uporabiti različne načine komuniciranja. Komunikacija lahko poteka enosmerno ali dvosmerno. Pri enosmerni komunikaciji so pobudniki prostorski načrtovalci, javnost pa je objekt preučevanja in vir informacij. Pri dvosmerni komunikaciji ima tudi javnost možnost sodelovanja in soodločanja. Primeri dvosmerne komunikacije so javnomnenjske ankete, delavnice, ki jih organizirajo prostorski načrtovalci, posredovanje predlogov, ki jih oblikuje javnost in podobno (Ogorelec, 1995; Wates, 1996). Ker je možnost participiranja omejena na javne razgrnitve, in sicer prek poziva v uradnem listu in na oglasnih deskah naročnika, pomeni, da poziv » vidijo « le redki zainteresirani deli javnosti. Ena od možnosti, da bi bila javna participacija v prostorskem načrtovanju bolj množična, so spletna orodja, ki omogočajo obveščanje in tudi osveščanje širše javnosti o posegih v skupni prostor. Javna participacija s pomočjo spletnih orodij bi morala javnosti dati moč, da lahko ustvarjalneje poseže v procese načrtovanja in vpliva nanje, saj gre pri prostorskem načrtovanju tudi za sooblikovanje kakovostnega prostora, v katerem bivamo in ustvarjamo.

\section{Javna participacija s pomočjo spletnih orodij}

Razvoj informacijske tehnologije prinaša možnost, da javnosti z novimi spletnimi orodji omogočimo lažje udeleževanje v postopkih načrtovanja. Hkrati imajo načrtovalci lažji dostop do poznavanja prostora, $\mathrm{v}$ katerem javnost biva in ustvarja. Franc Trček in Blaž Lenarčič (2003) sta ugotovila, da lahko uporaba spleta pripomore $\mathrm{k}$ boljšemu prostorskemu načrtovanju in boljši komunikaciji med vsemi vpletenimi v procesih prostorskega načrtovanja - načrtovalci, predstavniki občinske oblasti, resornimi državnimi službami in zainteresirano javnostjo. Prav z vključevanjem slednjih bi prostorsko načrtovanje pridobilo večjo družbeno vključenost, saj je lahko javnost vključena že zgodnejših fazah nastajanja prostorskih aktov v nekem prostoru.

Če združimo javno participacijo in spletna orodja, govorimo o elektronski participaciji (ang. electronic participation) ali e-participaciji (ang. e-participation), ki ima več definicij. Po Ann Macintosh in Angusu Whytu (2006) je e-participacija povezovanje med izvoljenimi predstavniki oblasti in različnimi javnostmi s pomočjo orodij informacijske tehnologije. Pri tem gre bolj za dajanje pobud in predlogov »od spodaj navzgor «, torej od javnosti proti izvoljenim predstavnikom oblasti, kot obratno. Simon Delakorda (2003: 92) razlaga e-javno participacijo kot »računalniško aplikacijo (spletne strani in spletni portali) za sistemsko normirano, javno, strokovno in politično soudeležbo državljanov pri sprejemanju politik (ang. policy), programov in načrtov o zadevah javnega pomena «. Lasse Berntzen idr. (2005) pa menijo, da je e-participacija skupina orodij za lažje komuniciranje med javnostjo in predstavniki oblasti. Med ta orodja uvrščajo tudi orodja geografskih informacijskih sistemov. Če torej povzamemo, je e-participacija splošno sprejet termin, ki zajema participacijo v različnih fazah demokratično-političnih procesov, ki je podprta z uporabo orodij informacijskih tehnologij.

Andrej A. Lukšič (2003) navaja te instrumente, ki jih lahko uporabimo za e-participacijo (glede na informacijski tok):

- Nagovarjanje (alokucija)

Instrumenti za nagovarjanje so lahko računalniška posredovana volilna kampanja, računalniško posredovana informacijska kampanja, informacijski centri in javne storitve.

- Posvetovanje (konzultacija)

Posvetovanje uporablja širše dostopen javni in bolje razvit javni informacijski sistem (na primer svetovni splet).

- Registracija

Registracija ima na voljo registrski sistem vladnih služb in javne uprave, računalniško podprto državljansko povpraševanje, e-referendum, e-volitve in e-izbore. 


\section{- Pogovarjanje (konverzacija)}

Za pogovarjanje je na voljo podporni sistem za skupinsko odločanje, seznam oglasnih desk, e-pošta, telekonference in e-mestne hiše (razpravljalni forumi).

Kot je bilo že omenjeno, so navedeni instrumenti vezani na uporabo $\mathrm{v}$ političnem sistemu, zato jih ne moremo neposredno uporabiti za participacijo v prostorskem načrtovanju. Instrumente e-participacije $\mathrm{v}$ prostorskem načrtovanju je torej treba še določiti, v pomoč pa so lahko spoznanja Iana Turtona in Jamesa Macgilla (2005), ki sta prepoznala dve vrsti participacije pri prostorskem načrtovanju - sočasno in nesočasno. Pri sočasni participaciji vsi udeleženci interaktivno sočasno sodelujejo prek elektronskega medija in uporabljajo enake planske akti, ki so dosegljivi na določenem strežniku. Pri nesočasni participaciji pa udeleženci niso sočasno prisotni in se njihovi odzivi shranjujejo za poznejše pregledovanje oziroma ocenjevanje in odgovarjanje.

Glavni težavi e-participacije sta slaba tehnična opremljenost javnosti in pomanjkanje zmogljivejših tehnoloških orodij. Javnost $\mathrm{v}$ glavnem ni dovolj dobro organizirana in nima potrebnih kadrovali sredstev, da bi lahko oblikovala zahtevno tehnično platformo (spletne strani, opremljene s spletnimi storitvami). To pa javnost postavlja v podrejen položaj, saj ji je lažje e-participiranje omogočeno le, če z njo sodelujejo tudi nevladne organizacije. Te so lahko bolje organizirane in največkrat premorejo potrebne kadre ali sredstva za vzpostavitev tehnične platforme za participacijo. Pomanjkanje uspešnih in zmogljivejšsih tehnoloških orodij, $s$ katerimi bi bilo mogoče analizirati in predstaviti podatke, pridobljene z e-participacijo, je izziv za trenutno raziskovanje e-participacije. Podatki, ki jih raziskovalci pridobijo z e-participacijo, so namreč največkrat nestrukturirani, pogosto jih je preveč, veliko jih ni uporabnih ter povzročajo izgubo časa in sredstev za urejanje. Zato se pojavlja vse večja potreba po raziskavah o uporabi pametnih orodij za e-participacijo in tudi o uporabi teh orodij pri drugih komunikacijskih napravah, kot so male pametne mobilne naprave. Pri tem se je $s$ pojavom socialnih omrežij pokazala tudi nova dimenzija e-participacije - e-participacija raznih interesnih skupin in javnosti na eni strani ter uradnih institucij, ki so do zdaj že uporabljale e-participacijo, na drugi strani (Macintosh idr., 2009).

\section{Javna participacija v okviru spleta 2.0 \\ 4.1 Koncept spleta 2.0}

$\mathrm{V}$ spletu imajo uporabniki in ponudniki informacij vsak svojo vlogo. Ponudnik prek spleta objavi informacije, ki jih uporabnik uporabi. Taka komunikacija je enosmerna, poteka od ponudnika proti uporabniku. $\mathrm{V}$ zadnjih nekaj letih se je ta komunikacija spremenila. S pojavom možnosti, kot so forumi, novičarske skupine in klepetalnice, ki so jih ponudniki omogočili obiskovalcem svojih spletnih strani, je tudi komunikacija začela potekati v obeh smereh (Best, 2006). Vseh informacij je danes na raznih spletnih straneh in spletnih portalih zelo veliko. Koliko jih je natančno, ni mogoče ugotoviti, saj se stanje dnevno spreminja. Količina spletnih strani in z njimi tudi informacij se je v zadnjih petih letih več kot podvojila ${ }^{[1]}$. Vzrok za to je splet 2.0.

Splet 2.0 sta leta 2004 prvič predstavila Tim O'Reilly in Dale Dougherty, predstavnika založbe O'Reilly Media, in sicer kot koncept, ki je zajemal pojavljanje novih spletnih strani po tako imenovanem »poku spletnega balona « ob koncu devetdesetih let 20. stoletja. Ta je uničil precej podjetij, ki so se ukvarjala s ponujanjem spletnih storitev. Preživela so podjetja, ki so omogočala uporabnikom, da lahko kreirajo vsebino strani in jo hkrati tudi uporabljajo (Maness, 2006; Anderson, 2007). Vendar se po mnenju Tima Bernersa - Leeja splet $2.0 \mathrm{v}$ ničemer ne razlikuje od spleta 1.0, ki je že v zasnovi uveljavljal principe povezanosti med uporabniki (glej internet 2). Splet 2.0 naj bi bil logično nadaljevanje razvoja spleta z novimi zmožnostmi, ki jih je omogočil razvoj programske in strojne opreme. Splet 2.0 poleg branja (ang. read) omogoča še pisanje (ang. write), kar pa je osnova za participacijo uporabnikov in razvoj socialnih omrežij. Enako razmišlja tudi Amy Shuen (2008), ki meni da pri spletu 2.0 ne gre za tehnologijo, temveč za spletna orodja, ki omogočajo ljudem, da lahko skupaj delajo, gradijo in si delijo svoje podatke, doživetja, slike in podobno. Tudi po Alexandru Bryanu (2006) splet 2.0 ni novo odkritje, temveč se z njim označuje mešanico med seboj podobnih tehnologij, uporabnih v spletu. Med njimi izstopa »socialna « programska oprema kot ena od glavnih komponent. Pod pojmom »socialna «se skriva programska oprema, ki omogoča uporabniku oziroma pripravljavcem spletnih strani ali storitev, da naredijo stran dostopno čim širšemu krogu uporabnikov. Podobno meni Paul Anderson (2007), ki navaja, da so pojmi »sodelovanje«, »prispevanje « in »skupnost « dnevno prisotni v spletu in so del socialnega omrežja, ki nastaja »pred očmi« uporabnikov spleta. Tovrstno omrežje pa potrebuje tehnologije, ki omenjene pojme spreminjajo $\mathrm{v}$ spletne storitve in programe, ki jih uporabljamo v spletu.

Uporaba teh specifičnih tehnologij je pripeljala do tega, da uporabnik ne samo $z$ uporabo osebnega računalnika, ampak tudi z uporabo mobilnih naprav, kot so pametni telefoni in tablice, lahko izmenjuje in deli informacije. $S$ tem sodeluje z drugimi uporabniki v spletu in tako udejanja participacijo (Blankenbach in Schaffert, 2010). Strani socialnega omrežja so spletne strani, ki s spletnimi storitvami omogočajo izdelavo javnega ali poljavnega profila. Ta omogoča uporabniku, da na spletno stran shrani svoje slike, videoposnetke, besedila in dru- 
ge podatke. Lahko si oblikuje tudi seznam drugih uporabnikov, s katerimi si deli te podatke. (Boyd in Ellison, 2008). Splet 2.0 je torej koncept, ki nima natančno določenih meja, temveč gre bolj za gravitacijsko območje, ki združuje spletne strani, ki uporabljajo podobno skupino principov in praks (O’Reily, 2005). Po Davidu Bestu (2006) spadajo med principe in prakse participacije uporabnikov bogata uporabniška izkušnja, dinamične vsebine spletnih strani, metapodatki in skalabilnost. Zadnja se kaže v prilagodljivosti računalniškega sistema in omrežja zahtevam uporabnika. Uporabniki spleta 2.0 so vsi, ki uporabljajo splet. Vendar imajo v okviru spleta 2.0 tudi možnost aktivnega sodelovanja pri poustvarjanju vsebin in ne samo pri dostopanju do njih. Zato storitve spleta 2.0 uporabniku omogočajo, da pridobi občutek pripadnosti in razpoznavnosti (Högg idr., 2006).

\subsection{Tehnologije, orodja in storitve spleta $\mathbf{2 . 0}$}

Kot smo ugotovili, spadata med najpomembnejše novosti, ki so izšle iz koncepta spleta 2.0, dodajanje podatkov v splet $\mathrm{s}$ strani uporabnikov in $s$ tem sooblikovanje spletnih strani, $s$ čimer lastniki strani pridobijo podatke o uporabnikih, njihova védenja in znanja, ki jih lahko uporabijo v različne namene. Uporabniki torej, kot rečeno, lahko sodelujejo. Participacijo jim omogočajo spletne storitve in spletne aplikacije. Osnova za izdelavo storitev in aplikacij je uporaba skupine tehnologij $\mathrm{z}$ imenom AJAX (okrajšava je sestavljena iz besed asynchronous javascript in XML) (Anderson, 2007). Programska oprema, napisana $\mathrm{v}$ tem programskem jeziku, omogoča, da izdelovalci spletnih strani te oblikujejo hitreje. Na spletnih straneh, ki ne uporabljajo te tehnologije, se celotna spletna stran ob vsaki spremembi ponovno naloži na uporabnikov računalnik. Spletne strani, ki so oblikovane s tehnologijo AJAX, pa omogočajo, da se med strežnikom in uporabnikom prenašajo le spremenjeni podatki, kar zelo pospeši nalaganje spletnih strani in hkrati odpravlja čakanje na strani odjemalca (Högg idr., 2006). Programska oprema, ki je nastala s tehnologijo AJAX, je omogočila, da so programi prijazni in preprosti za uporabo uporabnika. Zaradi tega jih lahko uporablja širok krog uporabnikov, ki lahko brez dodatnih znanj s področja računalništva dodajajo in spreminjajo vsebine na spletnih straneh (Kolbitsch in Maurer, 2006). Z uporabo takih storitev in aplikacij se lahko spletne strani tudi izboljšajo. Primer za to je storitev BitTorrent, ki je uporabnejša, če jo uporablja več ljudi (O’Reilly, 2005).

Nova tehnologija je omogočila tudi razvoj novih orodij in storitev, ki jih danes množično uporabljamo na spletnih straneh. Med osnovne storitve, ki so se pojavile s spletom 2.0, uvrščamo bloge (ang. blogs) oziroma spletne bloge (ang. weblogs), strani wiki, podcastinge (ang. podcast) in videobloge (ang. videoblogs), protokol RSS (ang. Really Simple Syndication), uvajanje označevanj s pomočjo označevalk/etiket (ang tags), ustvarjanje socialnih knjižnih oznak (ang. social bookmarks), socialna omrežja in spletno knjižnico (Alexsander, 2006; Kolbitsch in Maurer, 2006; Anderson, 2007).

- Blog ali spletni blog je spletni dnevnik. V primerjavi z osebnimi dnevniki, je blog dostopen vsakemu obiskovalcu spletne strani, na kateri je objavljen, temelji na osebnem podajanju vsebin in izraža mišljenje avtorja. Blog ni lektoriran in ni uredniško urejen. Omogoča dodajanje komentarjev bralcev in odgovore avtorja nanje. Objavljanje blogov in komentiranje torej omogoča komunikacijo oziroma izmenjavo mnenj med avtorjem in pisci komentarjev in tudi takojšnje komentiranje $\mathrm{v}$ časopisnem časovnem okviru, ki je lahko urni, dnevni ali tedenski (Benkler, 2006). Avtor bloga lahko posamezne objave označi, »etiketira « z enim geslom ali več teh. To pozneje omogoča hitrejše iskanje po sorodnih oznakah in da se spletni naslov bloga prenese v program, ki take naslove zbira in omogoča njihovo iskanje (Anderson, 2007). Blog je mogoče uporabiti tudi za predstavljanje uradnega mnenja, na primer, če ga avtor predstavi za predstavitev načrtovanega posega v prostor, $s$ čimer se lahko preveri odzive javnosti na tak poseg.

- Wiki je spletna stran, ki uporabniku omogoča, da na spletno stran doda določeno vsebino, ki jo lahko popravi drug uporabnik. Avtor tako imenovanega wikikoncepta je ameriški programer Ward Cunningham. Ime wiki izvira iz havajske besede » wikiwiki«, ki pomeni $\gg$ zelo hitro «, kar izraža tudi koncept spletnih strani wiki, to je hitro in preprosto urejanje spletnih vsebin s pomočjo sodelovanja med uporabniki. Wikistrani najbolje ponazarja Wikipedija (Ebersbach in Glaser, 2004), temeljijo pa na sodelovanju, kar pomeni, da uporabnik vnese besedilo, drug uporabnik lahko to popravi, tretji še kaj dopolni in podobno. Da lahko prvi uporabnik preveri, kaj je bilo popravljeno, imajo wikistrani možnost pregleda zgodovine in funkcijo, ki lahko vzpostavi predhodno stanje. Pri tem se postavljajo številna vprašanja, na primer, kaj pomeni, če se avtor prvotnega zapisa ne strinja s popravki in kaj se zgodi z intelektualno lastnino (Lamb, 2004), ne nazadnje pa tudi vprašanje »odprtosti « wikistrani. Wikistrani bi bile v okviru urbanističnega načrtovanja lahko uporabne za razjasnjevanje določenih terminov in pojasnjevanje postopkov.

- Podcasting je oblika zvočnega dnevnika, katerega vsebina so običajno predavanja, intervjuji, zapisi radijskih oddaj in podobno. Zapisi so v obliki MP3 in jih je mogoče predvajati na vseh predvajalnikih, ki podpirajo to obliko zapisa. Videoblogi so zapisi podobne vrste, le da vsebujejo tudi videovsebino. Zvočni podcasting in tudi videopodcasting sta zelo primerna za podajanje izobraževalnih vsebin (Rogers, 2005; Anderson, 2007).

- Protokol RSS je namenjen razširjanju podatkov s spletnih 
strani do uporabnikov. To pomeni, da uporabniku protokola RSS vsebin ni treba vedno znova iskati po spletnih straneh, ampak si bralnik RSS namesti na svoj računalnik in se na spletni strani, $s$ katere želi prejemati vsebine, naroči na želeno vsebino (Anderson, 2007). Prednost protokola RSS je, da omogoča samodejno razširjanje vsebin, zaradi česar se lahko uporabniki posvetijo branju ter ne izgubljajo časa z obiskovanjem spletnih strani in iskanjem novih vsebin. Uporaben je tudi za sporočanje o dogodkih in postopkih.

- Označevalke ali etikete so ključne besede, ki so pripete $\mathrm{k}$ informaciji, na primer sliki, videoposnetku, datoteki in podobno, ter pripomorejo $\mathrm{k}$ boljšemu opisu informacije in njenemu lažjemu iskanju v spletu. Etikete lahko informacijam doda vsak uporabnik in si s tem ustvari svoj nabor etiket, lahko pa jih tudi deli z drugimi uporabniki (Högg idr., 2006; Maness, 2006; Anderson, 2007). Označevalke so uporabne tudi za preverjanje javnega mnenja. Na spletni strani se na primer objavi primer rešitve posega $\mathrm{v}$ prostor in uporabnikom se omogoči, da lahko svoje strinjanje ali nestrinjanje izrazijo z označevalkami (na primer »všeč mi je«, »ni mi všeč « in podobno).

- Knjižne oznake omogočajo uporabniku, da shrani povezavo do spletne strani v svoj spletni brskalnik. Socialne knjižne oznake so podobne oznake, le da so shranjene na spletnih straneh, ki omogočajo shranjevanje knjižnih oznak (Högg idr., 2006; Maness, 2006). Uporabnik lahko knjižnim oznakam dodeli tudi označevalke in jih deli z drugimi uporabniki.

- Spletni geografski informacijski sistem (v nadaljevanju: GIS) je skupina orodij, ki omogočajo prikazovanje prostorskih načrtov skupaj z različnimi kartografskimi podlogami (satelitski posnetki, tridimenzionalni objekti in podobno). Sistemi GIS so z orodji spleta 2.0 pridobili možnost, da lahko uporabniki sodelujejo $\mathrm{z}$ vrisovanjem in vnašanjem prostorskih podatkov v naprej pripravljene grafične podloge.

\subsection{Analiza javne participacije pri prostorskem načrtovanju v okviru spleta 2.0}

Kot smo že ugotovili, je bila e-participacija doslej večinoma namenjena reševanju političnih vprašanj oziroma je omogočala sodelovanje javnosti zlasti v političnih procesih soodločanja. Glede predstavljenih značilnosti koncepta spleta 2.0 pa lahko sklepamo, da bi bile te storitve ob skrbnem naboru uporabne tudi za participacijo v procesih prostorskega načrtovanja, kar potrjuje tudi analiza javne participacije v okviru spleta 2.0, opravljena po metodi SWOT (preglednica 1).

\subsection{Ugotovitve analize}

Če povzamemo prednosti javne participacije v okviru spleta 2.0 in jih uporabimo v prostorskem načrtovanju, bi e-participacija javnosti omogočala, da bi lahko aktivneje sodelovala pri nastajanju prostorskih dokumentov in s tem pri soustvarjanju okolja, v katerem biva, ustvarja in preživlja prosti čas. Pripravljavci in naročniki (lokalne skupnosti, občine, država) bi lahko s pomočjo orodij spleta 2.0 omogočili javnosti dostop do podatkov in svojega dela že v zgodnejših fazah prostorskega načrtovanja. Procesi pripravljanja prostorskih dokumentov imajo svoje zakonitosti in s preglednostjo teh procesov je mogoče določiti tudi načine spremljanja poteka dela. $\mathrm{V}$ ta namen bi bilo treba pripraviti nabor spletnih storitev za prikazovanje zvočnih vsebin in videovsebin ter kartografskega gradiva, za posredovanje znanja in izobraževalnih vsebin, razpravljanje o vsebinah prostorskih dokumentov (blogi, forumi) in podobno. $S$ pametnim podajanjem informacij med projektom bi lahko javnost vselej sledila delu in se dovolj zgodaj primerno odzvala. Tako ne bi prihajalo do nepredvidenih zaostankov zaradi prevelikega števila pripomb javnosti. Prostorski načrtovalci pa bi lahko sledili potrebam in željam ljudi ter njihovemu razmišljanju. Orodja spleta 2.0 torej omogočajo, da je končni rezultat prostorskega načrtovanja rešitev, ki pomeni kompromis $\mathrm{v}$ dobro vseh udeleženih.

Ugotovili smo, da orodja spleta 2.0 omogočajo učinkovito e-participacijo. Ta se lahko kaže kot prispevanje zamisli in pobud o posegu v prostor. Lahko pa se izraža kot slabost, kot kritična ocena rešitve problema s strani strokovne javnosti, ki je bila povabljena $\mathrm{k}$ e-participaciji in nima vloge prostorskega načrtovalca. Javnost se lahko udeležuje tudi s pomočjo svojega védenja o prostoru, $\mathrm{v}$ katerem biva, saj lahko posreduje lokalno znanje poplavah, o geoloških posebnostih in podobno. Splet kot osnova e-participacije omogoča participacijo prek domačega računalnika ali računalnika na delovnem mestu oziroma kje drugje, na primer v domu starejših občanov. Uporabnik je lahko pri svojem dejanju anonimen ali pa se predstavi s svojim pravim imenom. Do neke mere je anonimnost vsekakor prednost, saj omogoča uporabnikom, ki se ne želijo izpostavljati ali jih tako izpostavljanje moti, da vseeno sodelujejo in $s$ tem pomagajo do boljše rešitve problema. Vendar pa Anne Macintosh idr. (2009) opozarjajo na majhno število razpravljavcev v pogovornih skupinah (na forumih) in nizko kakovost debat, ki tam potekajo. Prednost je tudi dosegljivost e-participatorne spletne strani s katerega koli računalnika ali z druge mobilne naprave (pametni telefon, tablični računalnik, prenosnik), saj je taka stran vedno dosegljiva štiriindvajset ur na dan med trajanjem načrtovanja določenega prostorskega načrta in ne samo tiste dni, v katerih poteka fizična javna razgrnitev. 
Preglednica 1: Analiza potencialne javne participacije pri prostorskem načrtovanju z orodji spleta 2.0 po metodi SWOT

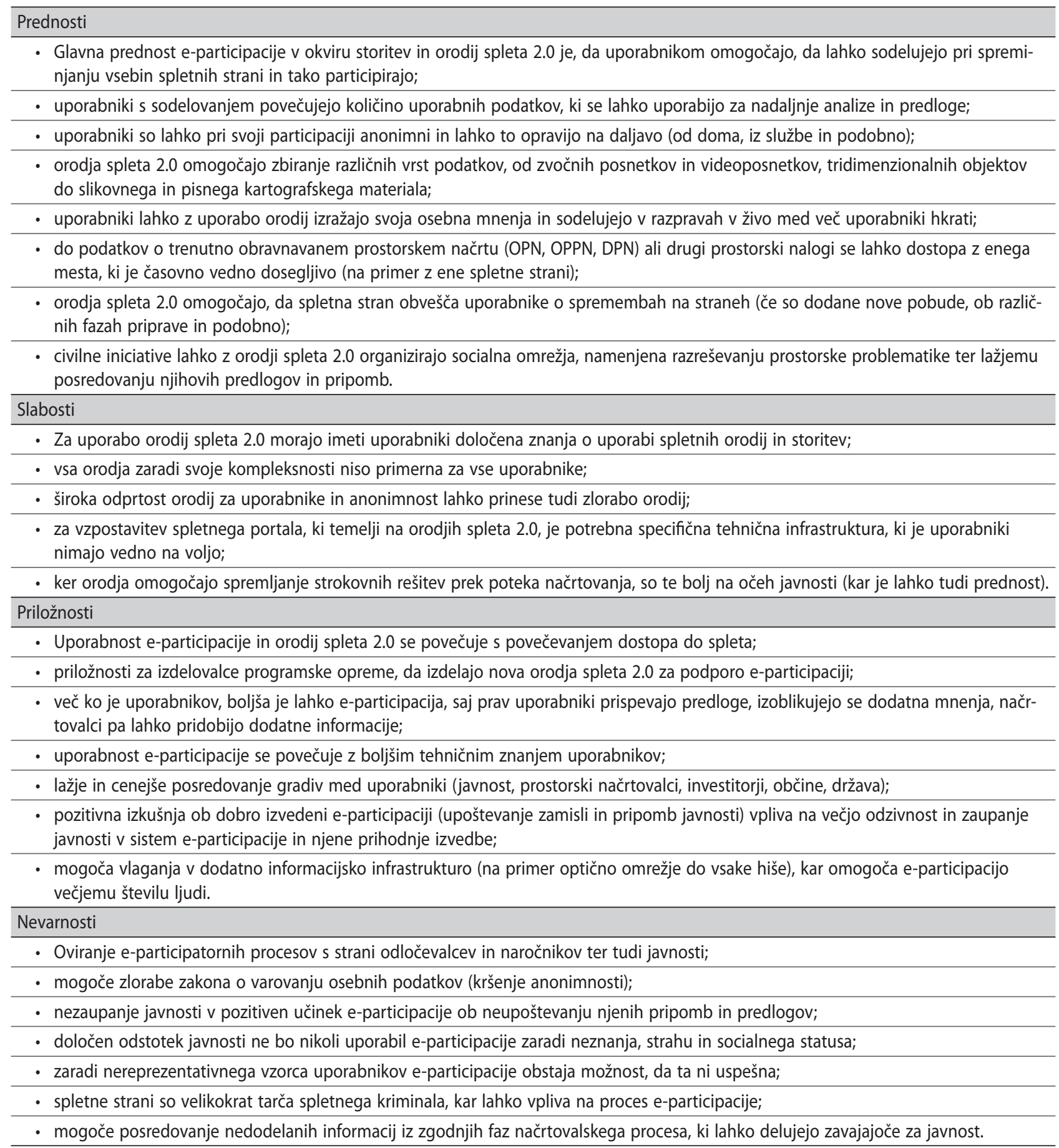

Uporaba spleta 2.0 pri sodelovanju javnosti v procesu prostorskega načrtovanja bi se lahko izkazala za prijaznejšo kot klasično sodelovanje javnosti na javnih razgrnitvah. Prek spleta bi sodelovalo več ljudi, vzorec populacije, ki bi aktivno sodelovala, bi bil večji, torej bi načrtovalec dejansko dobil boljšo sliko o mnenju in težnjah ljudi. Pripombe bi bile lahko bolj utemeljene, premišljene in ne impulzivne, kot so lahko na javnih obravnavah. Naročnik bi s tem, ko bi pridobil več mnenj javnosti in več konstruktivnih pripomb, dobil več informacij, pri- pombe pa bi lahko razširili tudi v smislu časovne komponente, saj dajanje pripomb ne bi bilo omejeno le na čas razgrnitve, ampak morda na ves čas od objave sklepa o začetku priprave akta. Občine bi kot naročnice morale svoj delež izkazati tudi s posodobitvijo telekomunikacijske infrastrukture oziroma $\mathrm{z}$ vzpostavitvijo optičnega omrežja tam, kjer ga še ni. S tem bi omogočili dostop do spletnih e-participatornih portalov tudi javnosti, ki do zdaj te možnosti ni imela. Jennifer Evans-Cowley in Justin Hollander (2010) ugotavljata, da določenih 
orodij ni mogoče uporabiti, če ni na voljo dovolj hitre infrastrukture. Nadgradnja na splet višjih hitrosti (ang. high-speed internet) bi omogočila, da bi lahko uporabili tudi orodja spleta 2.0, kot je GIS. Spletna orodja ponujajo tudi priložnost za izobraževanje javnosti o uporabi spletnih storitev in strokovnih pojmih, ki se pojavljajo v postopkih urejanja prostora. Bolj ko uporabniki e-participacije poznajo prostorsko problematiko in uporabo spletnih orodij, lažje sodelujejo. Vendar pa Koekoek Arjen idr. (2009) opozarjajo, da sistemi za e-participacijo, ki so preveč kompleksni in zahtevajo od uporabnika preveč osebnih podatkov, ne spodbujajo participacije, ampak uporabnike od nje odvračajo. To je priložnost za razvijalce spletnih orodij in spletnih strani, da izdelajo nova orodja in pripravijo spletne strani, ki so prijaznejše do uporabnikov in prirejene za e-participiranje v prostorskem načrtovanju. Priložnosti je torej veliko - na primer pri naročnikih sprejet prostorski načrt in z njim priložnosti za razvoj skupnosti, pri prostorskih načrtovalcih dobro opravljen prostorski načrt in priložnosti za nove naloge, pri investitorjih možnost za investiranje in oplemenitenje vloženega kapitala ter pri javnosti spoznanje, da so predlagane zamisli in predlogi obrodili sadove in da so sami pripomogli $\mathrm{k}$ boljšemu okolju, v katerem bivajo -, vse pa so odvisne od pozitivne izkušnje, ki jo po končani e-participaciji dobijo prostorski načrtovalci, investitorji, naročniki (občine, država) in javnost.

Kot je razvidno iz analize SWOT, so izdelovalci prostorskih načrtov in naročniki (lokalne skupnosti, občine in država) pri uporabi e-participacije zaradi »javnega vpogleda « v svoje delo pod določenim pritiskom. Izdelava prostorskih načrtov brez e-participacije poteka odmaknjeno od oči javnosti v načrtovalskih uradih. Tam poteka načrtovalsko delo z upoštevanjem smernic nosilcev urejanja prostora, vlog občanov ter želja naročnikov in investitorjev. Običajno je dolgotrajnejše usklajevanje med naročniki, prostorskimi načrtovalci in nosilci urejanja prostora. Uporabniki načrtov, torej javnost, večinoma teh zapletenih poti ne vidijo in pogosto ne vedo oziroma ne razumejo, zakaj do določenih rešitev ne pride, saj so z delom seznanjeni ob javni razgrnitvi. Pri e-participaciji pa mora ves postopek priprav prostorskega načrta potekati prek spletnih strani, opremljenih z orodji spleta 2.0, ki v tem primeru prevzamejo vlogo poročevalca poteka dela (na primer objave RSS) in tudi zbiralca določenih informacij (spletne ankete), ki jih načrtovalci lahko uporabijo pri svojem delu. Javnost ima tako ves čas vpogled v delo, ki ga seveda lahko tudi komentira. Komentar lahko pomaga prostorskim načrtovalcev in naročniku $\mathrm{v}$ procesih prostorskega načrtovanja.

Nevarnost javne participacije s pomočjo orodij spleta $2.0 \mathrm{je}$, da določen del javnosti pri spremljanju takih procesov sodeluje le zato, »da opozori nase «, s čimer pogosto onemogoča normalen delovni proces. Mednje spadajo tudi tisti, ki nasprotujejo predlogom načrtovalcev zaradi tako imenovanega sindroma NIMBY (ang. not in my backyard - ne na mojem dvorišču) in so pripravljeni storiti vse, da do posegov v prostor ne bi prišlo na njihovih parcelah ali v bližini teh. Res je tudi, da se taki posamezniki pojavljajo tudi na javnih razgrnitvah, vendar je lahko delež teh pri e-participaciji veliko večji. Prvič zato, ker je e-participacija dosegljiva velikemu številu ljudi, ki so lahko anonimni, in drugič, ker je lahko struktura uporabnikov zelo različna od strukture prisotnih na javni razgrnitvi. Pri javni razgrnitvi so negativno nastrojeni večinoma lastniki zemljiščc, na katere prostorski načrt vpliva neposredno ali posredno in ki lahko z njegovo uveljavitvijo kaj izgubijo, pri e-participaciji pa so to večinoma mlajši uporabniki, ki še niso lastniki ter jim je tako nasprotovanje le »šport « in ne konstruktivno prispevanje k skupni stvari.

Ker prostorsko načrtovanje pogosto vsebuje precej podatkov, ki so sicer po Zakonu o varovanju osebnih podatkov (Ur. l. RS, št. 86/2004) tajni (na primer lastništva parcel in nepremičnin), je lahko ena od nevarnosti tudi objava takih podatkov na strani e-participacije. Zato morata biti naročnik in načrtovalec na to še posebej pozorna, saj imata lahko zaradi tega težave, na kar opozarjajo številni avtorji (na primer Hoffman, 2003; Sieber, 2006). Med nevarnosti javne participacije v okviru spleta 2.0 spadajo tudi težave pri vzpostavljanju tehnične ali strojne platforme za e-participacijo. Ta je lahko dokaj zapletena in potrebuje tudi stalnega skrbnika, ki preverja njeno delovanje in odpravlja težave, ki nastanejo ob njenem delovanju. $V$ analizi spletnih strani v 590 ameriških mestih z več kot 50.000 prebivalci so ugotovili, da to velikokrat pomeni oviro pri vzpostavitvi e-participacije (Conroy in Evans-Cowley, 2006). Po Zakonu o prostorskem načrtovanju (Ur. l. RS, št. 33/2007 in nadaljnje spremembe) mora tehnično platformo vzpostaviti naročnik prostorskega načrta, zaradi česar se pojavlja vprašanje o (ne) pristranskosti, in sicer ali bo platforma omogočala vse možnosti javne participacije ali samo tisto, ki je bolj po volji naročnika.

Določen delež javnosti ne bo nikoli uporabljal e-participacije. Razlogov je lahko več: od tega, da nimajo vsi osebnih računalnikov ali jih ne znajo uporabljati, do tega, da nimajo možnost dostopa do spleta. Tudi če bi do spleta uredili javni dostop, na primer v prostorih občine za vse občane, te možnosti ne bi izkoristili vsi. Poleg tega del prebivalstva, zlasti starejši ljudje, še nikdar ni uporabljal osebnega računalnika ali spleta in ga verjetno tudi nikoli ne bo. Podobno razmišljajo tudi drugi avtorji, na primer Jo Saglie in Signy Irene Vabo (2009) za Norveško. Rebecca Moody (2007) ugotavlja, da če uporabniki, ki nimajo računalnikov in jih ne znajo uporabljati, in naročniki ne znajo uporabiti e-participacije za razreševanje problemov, ta ne doseže svojega namena. Ker družba postaja vse bolj informacijska, se delež prebivalstva, ki nima dostopa do spleta in potrebnega znanja, iz leta $v$ leto manjša in pomeni manjši- 
no javnosti, ki je pripravljena sodelovati. Zaupanje javnosti v mogoče spremembe, ki jih lahko prinese e-participacija, je zelo pomembno za uspeh nadaljnjih e-participacij. Vsekakor pa je treba javnosti omogočiti, da lahko spremlja, kako se predlagana sprememba upošteva $\mathrm{v}$ procesu prostorskega načrtovanja. Sicer se lahko javnost čuti ogoljufano, na kar opozarjajo tudi Koekoek Arjen idr. (2009). To pomeni, da je uspeh e-participacije $\mathrm{v}$ glavnem $\mathrm{v}$ rokah naročnikov, prostorskih načrtovalcev in investitorjev. In prav to je jedro težav, saj ti raje vidijo, da se zadeve razrešijo brez vpletanja javnosti. Podobno meni Lee Komito (2007), ko govori o sistemih, ki lahko izboljšajo lokalno e-participacijo, vendar le če jo podpirajo naročniki.

\subsection{Predlogi za uporabo orodij spleta $2.0 \mathrm{v}$ prostorskem načrtovanju}

- Za e-participacijo v prostorskem načrtovanju je uporabna neformalna oblika javne participacije. $V$ ta namen bi lahko, kot meni Andrej A. Lukšič (2003), uporabili pogovarjanje (konverzacijo) in instrumente, povezane z njim, na primer oglasne deske (forumi), elektronsko pošto, RSS, telekonference, elektronske ankete in drugo.

- Prednost, ki jo omogočajo orodja spleta 2.0 (na primer RSS), je vsekakor tudi obveščanje o spremembah, ki se zgodijo na spletni strani, na kateri je predstavljen prostorski načrt. Uporabnik, ki ne želi vsakodnevno pregledovati, kaj je novega na spletni strani, lahko s spletne strani dobiva le obvestila o novem dogodku in si stran ogleda, če meni, da je sprememba pomembna, ter se primerno odzove.

- Določena orodja spleta 2.0 omogočajo organizacijo socialnega omrežja, kar lahko izkoristijo različne civilne iniciative. Socialno omrežje omogoča razširjanje zamisli in organizacijo enakomislečih uporabnikov omrežja, ki $s$ tem pridobijo moč in lahko vplivajo na spreminjanje prostorskega načrta oziroma uveljavitev svojih interesov.

- Orodja spleta 2.0 omogočajo tudi izdelavo izobraževalnih vsebin, ki jih je mogoče ponuditi obiskovalcem e-participatornih spletni strani. Z njimi se lahko javnost izobražuje o postopkih prostorskega načrtovanja ali strokovnih pojmih, ki se pojavljajo med prostorskim načrtovanjem in so javnosti tuji.

- Pri pojavu določenega števila nekonstruktivnih udeležencev (udeleženci, ki uporabljajo žaljive komentarje, sovražni govor in podobno), ki lahko vplivajo na potek e-participacije, morajo imeti prostorski načrtovalci pripravljene določene vzvode ali orodja spleta 2.0. Z njimi morajo omogočiti produktivno udejstvovanje javnosti, ki je pripravljena sodelovati ustvarjalno in ne destruktivno.

- Nezanemarljiv je lahko tudi vpliv spletnih »kriminalcev« oziroma »hekerjev«, ki lahko v določenem trenutku ustavijo delovanje spletnih strežnikov, na katerih so strani e-participacije in s tem onemogočijo sodelovanje. Seveda je mogoče take težave ublažiti z določenimi varnostnimi mehanizmi, ki jih lahko uporabijo upravljavci spletnih strani.

- Prostorsko načrtovanje pogosto vsebuje precej podatkov, ki so velikokrat kartografski (zemljevidi različnih vsebin, na primer prikaz parcelnih mej, raznih varstvenih območij in podobno) in prikaz teh je lahko tehnično zahteven. $\mathrm{V}$ tem primeru je orodje GIS zelo primerno za njihov prikaz, saj omogoča tudi vnašanje novih podatkov in spreminjanje obstoječih. GIS je idealno orodje za prostorske načrtovalce (za izdelavo prostorskih načrtov) in tudi za ostale uporabnike spletnih strani (za prikazovanje prostorskih načrtov).

- Tehnična platforma za izvedbo e-participacije je lahko zelo draga in zapletena. Ker javnost največkrat nima možnosti, da bi vzpostavila svojo, neodvisno tehnično platformo, so mogoča rešitev neodvisne organizacije, ki bi omogočale najemanje ali posojanje takih sistemov in bi zanje tudi skrbele.

\section{Sklep}

Na podlagi analize SWOT in raziskave številnih virov lahko predvidevamo, da prednosti in priložnosti odtehtajo slabosti. Pomembno je, da je e-participacija pravilno izpeljana. Najpomembnejši prispevek orodij spleta 2.0 je, da lahko javnost $\mathrm{z}$ njimi sodeluje v vseh fazah prostorskega načrtovanja. Lahko je seznanjena tudi z vsemi podatki, ki so osnova za pripravo načrtov prav prek spleta. Postopek priprave postane transparenten in javnosti jasnejši. Javnost prav tako spozna težave, s katerimi se spopadajo naročnik in načrtovalci, ki po eni strani razumejo želje ljudi, po drugi strani pa jim ne morejo vedno ugoditi. Vendar se je treba zavedati, da izpeljava e-participacije $\mathrm{v}$ prostorskem načrtovanju ni preprosta, zahteva dobro tehnično platformo in podporo, veliko priprav s strani pripravljavcev ter tudi precej kakovostne in strokovne reklame, da se k e-participaciji pritegne čim večje število ljudi. Nadaljnje raziskave bi se morale usmeriti v izdelavo nabora orodij spleta 2.0, ki so uporabna za e-participacijo v prostorskem načrtovanju. Med taka orodja lahko štejemo bloge, wikistrani, orodja GIS, različne izobraževalne vsebine, podane s videocastingi, in podobno. Predlagati pa bi bilo treba tudi morebitna nova orodja, ki bi jih lahko potrebovali za uspešno e-participacijo v prostorskem načrtovanju. Prav tako bi morali raziskati različne tehnične platforme (spletni strežniki, programska oprema, orodja spleta 2.0 in podobno) in predlagati najugodnejše s stališča cenovne dostopnosti, prijaznosti uporabniku in načina vzdrževanja oziroma neodvisnosti ponudnika take platforme. 


\section{Opombe}

[1] Po ocenah, ki jih je v kazalnikih objavil spletni ponudnik Yahoo, je bilo leta 2005 na svetu več kot 19,2 milijarde spletnih strani. Za isto leto je spletni ponudnik Netcraft objavil, da je bilo zabeleženih 72 milijonov aktivnih spletnih domen. To pomeni, da je bilo v povprečju na aktivno spletno domeno zabeleženih 263 spletnih strani. Podatki za najnovejšo statistiko aktivnih spletnih strani, ki imajo svojo registrirano domeno, kažejo, da jih je bilo v oktobru 2011 več kot 504 milijone, od teh je bilo več kot 170 milijonov aktivnih (glej internet 1). Če ima torej vsaka aktivna spletna stran vsaj 263 strani, pomeni, da je trenutno na svetu 45,5 milijarde spletnih strani. To je le ocena, saj ni mogoče zaobjeti vseh spletnih strani.

\section{Viri in literatura}

Alexander, B. (2006): Web 2.0: A new wave of innovation for teaching and learning? Educause Review, 41(2), str. 32-44.

Anderson, P. (2007): What is web 2.0? Ideas, technologies and implications for education. JISC Technology \& Standards Watch. Dostopno na: www.jisc.ac.uk (sneto 15. 12. 2011).

Arnstein, S. R. (1969): A ladder of citizen participation. Journal of The American Institute of Planners, 35, str. 216-224. DOI: 10.1080/01944366908977225

Benkler, Y. (2006): The wealth of networks: How social production transforms markets and freedom. New Haven, Yale University Press.

Berntzen, L., Steinmann, R., in Krek, A. (2005): Innovative use of Geographic Information Systems to facilitate collaboration between the government and citizens. V: Cunningham, P., in Cunningham, M. (ur.): Innovation and the knowledge economy: Issues, applications, case studies. Amsterdam, IOS Press.

Best, D. (2006): Web 2.0: Next big thing or next big internet bubble? Eindhoven, Technische Universiteit Eindhoven.

Blankenbach, J., in Schaffert, M. (2010): A SDI and web 2.0 based approach to support e-participation in municipal administration and planning strategies. Prispevek je bil predstavljen na konferenci z naslovom FIG Congress 2010, Facing the Challenges - Building the Capacity, ki je potekala od 11. do 16. aprila v Sydneyju v Avstraliji. Tipkopis.

Boyd, D. M., in Ellison, N. B. (2008): Social network sites: Definition, history, and scholarship. Journal of Computer-Mediated Communication 13(1), 210-230. DOI: 10.1111/j.1083-6101.2007.00393.x

Carver, S., Evans, A., Kingston, R., in Turton, I. (2001): Public participation, GIS, and cyberdemocracy: evaluating on-line spatial decision support systems. Environment and Planning B: Planning and Design, 28, str. 907-921. DOI: 10.1068/b2751t

Conroy, M. M., in Evans-Cowley, J. (2006): E-participation in planning: an analysis of cities adopting on-line citizen participation tools. Environment and Planning C: Government and Policy, 24(3), str. 371-384. DOI: $10.1068 / \mathrm{c} 1 \mathrm{k}$

Delakorda, S. (2003): Elektronska demokracija v refleksiji izbranih politoloških kategorij: politične participacije, politične moči in politične akcije. V: Lukšičc, A. A., in Oblak, T. (ur.): Knjižna zbirka Hermes: S poti v digitalno demokracijo, str. 81-98. Ljubljana, Fakulteta za družbene vede.

Ebersbach, A., in Glaser, M. (2004): Towards emancipatory use of a medium: The Wiki. International Journal of Information Ethics, 11(2), str. 1-9.
Evans-Cowley, J., in Hollander, J. (2010): The new generation of public participation: Internet-based participation tools. Planning Practice \& Research, 25(3), str. 397-408. DOI: 10.1080/02697459.2010.503432

Evropska komisija (2001): Bela knjiga o evropskem upravljanju. COM(2001) 428 dokončno. Bruselj.

Evropska komisija (2003a): Direktiva 2003/4/ES o dostopu javnosti do informacij o okolju. Uradni list Evropske unije L 41. Bruselj.

Evropska komisija (2003b): Direktiva 2003/35/ES o sodelovanju javnosti pri sestavi nekaterih načrtov in programov $\mathrm{v}$ zvezi z okoljem. Uradni list Evropske unije L 156/14. Bruselj.

Hoffman, M. C. (2003): The ethic of public data dissemination: Finding the »public in public data. Prispevek je bil predstavljen na konferenci z naslovom 2nd Annual Public Participation GIS Conference, ki je potekala od 20. do 22. julija v Portlandu v ZDA. Tipkopis.

Högg, R., Meckel, M., Stanoevska-Slabeva, K., in Martignoni R. (2006): Overview of business models for Web 2.0 communities. Prispevek je bil predstavljen na konferenci z naslovom GeNeMe 2006, ki je potekala od 28. do 29. septembra v Dresdnu v Nemčiji. Tipkopis.

Internet 1: http://news.netcraft.com (sneto 10. 11. 2011).

Internet 2: http://www.ibm.com (sneto 2. 11. 2011).

Kingston, R. (1998): Accessing GIS over the web: an aid to public participation in environmental decision making. Leeds, School of Geography, University of Leeds.

Kolbitsch, J., in Maurer, H. (2006): The transformation of the web: How emerging communities shape the information we consume. Journal of Universal Computer Science, 12(2), str. 187-213.

Koekoek, A., van Lammeren, R., in Vonk, G. (2009): The potential of integrating e-participation in planning support systems. URISA Journal, 21(2), str 39-49.

Komito, L. (2007): Community and inclusion: The impact of new communications technologies. Journal of Sociology, 16(2), str. 77-96.

Kos, D., (2005): Participativna prenova mesta [Participatory urban renewal]. Urbani izziv, 16(2), str. 16-23 [pp. 141-146]. DOI: 10.5379/urbaniizziv-2005-16-02-002

Kyem, P. A. K. (1998): Promoting local community participation in forest management through the application of Geographic Information Systems. An experience from southern Ghana. Prispevek je bil predstavljen na zborovanju z naslovom Empowerment, Marginalization, and Public Participation GIS, ki je potekala od 15. do 17. oktobra v Santa Barbari v ZDA. Tipkopis.

Lamb, B. (2004): Wide open spaces: Wikis, ready or not. EDUCAUSE Review, 39(5), str. 36-48.

Lavtar, R. (2007): Sodelovanje prebivalcev v slovenskih občinah. Participacija prebivalcev pri odločanju o javnih zadevah na lokalni ravni v Sloveniji. Maribor, Zbirka Lex localis, Inštitut za lokalno samoupravo in javna naročila.

Macintosh, A., Coleman, S., in Schneeberger, A. (2009): Epaticipation: The research gaps. V: Macintosh, A., in Tambouris, E., (ur.): Electronic participation, str. 1-11. Berlin, Springer Verlag. DOI: 10.1007/978-3-64203781-8_1

Macintosh, A., in Whyte, A. (2006): Evaluating how e-participation changes local democracy. London. Prispevek je bil predstavljen na delavnici z naslovom eGovernament Workshop '06, ki je potekala 11. septembra v Londonu v Veliki Britaniji. Tipkopis.

Moody, R. (2007): Assessing the role of GIS in e-government: A tale of e-participation in two cities. V: Wimmer, M., Scholl, H., in Gronland, 
A. (ur.): Lecture notes in computer science 4656, str. 354-365. Berlin, Springer Verlag. DOI: 10.1007/978-3-540-74444-3_30

Moore, C. N., in Davis, R. (1997): Participation tools for better land-use planning. Sacramento, Centre for livable communities.

O'Reilly, T. (2005): What Is Web 2.0. Design patterns and business models for the next generation of software. Dostopno na: http://oreilly.com (sneto 13. 12. 2011).

Ogorelec, B. (1995): Komuniciranje z javnostjo, priročnik za urbaniste. Ljubljana, Urbanistični inštitut Republike Slovenije.

Peng, Z.-R. (2001): Internet GIS for public participation. Environment and Planning B: Planning and Design, 28(6), str. 889-905. DOI: 10.1068/ b2750t

Ploštajner, Z. (2003): Participacija v prostorskem planiranju [Participation in physical planning]. Urbani izziv, 14(1), str. 51-54 [pp. 51-54]. DOI: 10.5379/urbani-izziv-2003-14-01-008

Pogačnik, A. (1999): Urbanistično planiranje. Ljubljana, Univerza v Ljubljani, Fakulteta za gradbeništvo in geodezijo.

Rogers, G. P. (2005): Podcasting and its role in semantic social networks, the Web 2.0, and the semantic web. Special Issue on Semantic Web and Social Networks, AIS SIGSEMIS Bulletin, 2(3/4), str. 57-61.

Rocha, E. (1997): A ladder of enpowerment. Journal of Planning Education and Research, 17(1), str. 31-44. DOI: 10.1177/0739456X9701700104

Saglie, J., in Vabo, S. I. (2009): Size and e-democracy: Online participation in Norwegian local politics. Scandinavian Political Studies, 32(4), str. 382-401. DOI: 10.1111/j.1467-9477.2009.00235.x

Shuen, A. (2008): Web 2.0: A strategy guide. Sebastopol, O'Reilly Media.

Sieber, R. (2006): Public participation geographic information systems: A literature review and framework. Annals of the Association of American Geographers, 96(3), str. 491-507. DOI: 10.1111/j.1467-8306.2006.00702.x

Trček, F., in Lenarčič, B. (2003): Internet kot medij politične participacije: primer priprave novega prostorskega plana Mestne občine Ljubljana. V: Lukšič, A. A., in Oblak, T. (ur.): Knjižna zbirka Hermes: S poti v digitalno demokracijo, str. 99-110. Ljubljana, Fakulteta za družbene vede.

Turton, I., in Macgill, J. (2005): Building a standards based collaborative GIS. Prispevek je bil predstavljen na konferenci z naslovom 8th International Conference on GeoComputation, ki je potekala 1.-3. avgusta v Ann Arbor v Združenih državah Amerike. Tipkopis.

Wates, N. (1996): Action planning : How to use planning weekends and urban design action teams to improve your environment. London, The Prince of Wales's Institute of Architecture.

Waidemann, I., in Femers, S. (1993): Public participation in waste management decision making: Analysis and management of conflicts. Journal of Hazardous Meterials, 33(3), str. 355-368. DOI: 10.1016/03043894(93)85085-S

Zakon o dostopu do informacij javnega značaja. Uradni list Republike Slovenije, št. 24/2003. Ljubljana.

Zakon o prostorskem načrtovanju. Uradni list Republike Slovenije, št. 33/2007 in nadaljnje spremembe. Ljubljana.

Zakon o umeščanju prostorskih ureditev državnega pomena v prostor. Uradni list Republike Slovenije, št. 80/2010. Ljubljana.

Zakonu o varovanju osebnih podatkov. Uradni list Republike Slovenije, št. 86/2004. Ljubljana. 